\title{
Comparative Analysis of College Students In View of Gender Issues
}

\section{Ikhsan Siregar1, Yusuf Hanifiah², Muhammad Arifin Nasution³, Abdillah Arif Nasution4, Muhammad Anggia Muchtar' ${ }^{5}$ Tigor H. Nasution 6}

\author{
Department of Industrial Engineering, Faculty of Engineering ${ }^{12}$ \\ Department of State Administration, Faculty of Social and Political Science, \\ Department of Accounting, Faculty of Economic and Bussiness ${ }^{456}$, \\ University of Sumatera Utara, Medan, Indonesia \\ ikhsan.siregar@usu.ac.id
}

\begin{abstract}
Education is a very important element for the development of a nation. Before the days of independence, Indonesians educations are for men only, until finally through the momentum that involves a female character who has become a driving force of education and education for female in Indonesia. Education does not currently distinguish between genders; females education is also an important factor for the development and application of science. Unlike the past, education was now free to among female, and maley female now taking the highest education level in education. Through this research can be seen comparing academic achievements of men and female. This study analyzed the number of female and men are accepted into college country, through this research can also be seen how the comparison of academic achievement (GPA) of college graduates over the past five years. Data is collected on one of the state universities in Indonesia. With the results of the data analysis shown that female no longer be a complement or a follower of the education system, but competition for the men in the world get an education, particularly the degree program. Results of this study was the presentation of data obtained through the survey and the data is expected to be developed for advanced research related to gender issues that have been debated about the intelligence level between genders.
\end{abstract}

Keywords: Gender, Male, Female, Analysis, science

\section{INTRODUCTION}

Education in Indonesia over this time for female has gained more recognition, it is absolutely different with the days before the first colonization. In the history of Indonesia, Kartini is a female character that was interesting to be represent, moreover Kartini appeared in the era of thick feudalism and modern imperialism began to appear. Kartini brought the concept of progress and freedom in the realm of thought and the development of Indonesia through a point that was concerned about the education of his people. Kartini is unforgettable by the time record of Indonesia which was both indirectly and directly lay the foundations of thought and movement to changes in the development of Indonesia both as a country and its influence in the culture.

Education today is not only dominated by men, even in some areas of female can even reach better than male level of education. In Indonesia, the total population is about 255 million people where 126.8 million consisted of female, these data reported by Statistics Indonesia in 2015.

Research on higher education fluently to do in the world, because the issue of gender is very interesting to investigate. This study takes the object in one of the state universities in North Sumatra. Figure 1 outlines the percentage of the population of North Sumatra comparison by gender. 


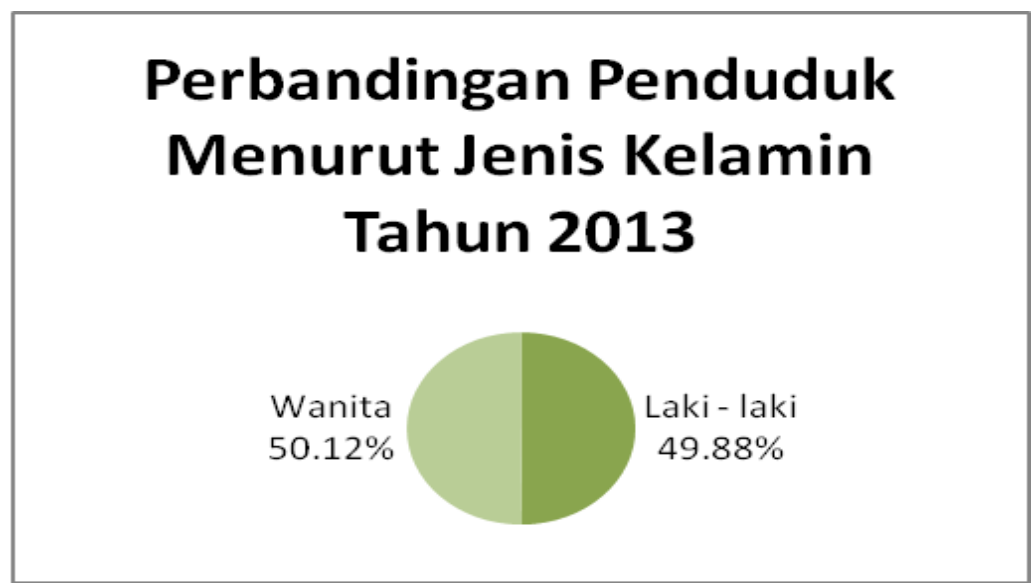

Source: Central Bureau of Statistics Republic of Indonesia Figure 1. Comparison of Population Gender in North Sumatra Province

The previous study that discusses gender and college is in Turkey, where the study discusses the causes of gender inequality in higher education in Turkey (Dogan, 2011:691). Other studies mention gender history and the history of female in higher education: an educational innovation project was done in Spain (Garcia, 2014: 289). Other studies mention that gender discrimination and education practitioners, it is related to the way the research of possible solutions (Popa, 2014 ) 459). As in Indonesia, researchers from Uzbekistan also viewed from the side of growing countries, where the intelligence in education is associated with gender issues (Salahodjaev, 2015: 97). In fact, researchers from Sri Lanka tried to examine this issue in Indonesia, the research shows that, to a certain extent, education does not empower female in middle-income countries such as Indonesia (Samarakoon, 2015: 428).

Other studies that pay attention in the importance of higher education for female mentioned that female's success factors of leadership in higher education (Shahtalebi, 2011: 3644). It is clearly stated that education for female is important and necessary. Even the studies that have been conducted in Indonesia on gender equality and social capital as an indicator of rural development in Indonesia (Case: Malang, Indonesia) (Surjono, 2015: 370).
If we find out a conclusion based on previous studies above, it is quite clear that higher education is very important. Through this study wanted to see that the level of education of female in higher education, this research was done because they have not seen studies that look at the higher education level seen from the number of female who received at public universities and academic achievement accomplished female, particularly in North Sumatra. This study will try to compare between men and female both from the number of students accepted and in terms of graduates through academic achievement or academic achievement index of college graduates.

\section{METHOD}

The method used in this research is based of the methods of Academic-Based Management Information System, the data retrieved obtained from the State University became the object and partly data captured from the Ministry of Research, Technology and Higher Education of the Republic of Indonesia.

Management information system here is the recruitment process supporting data when the students get into college and filled in their personal data in accordance with the request from the college.

This data collection is also obtained from the Higher Education report format that can be accessed from forlap.dikti.go.id. 
The recapitulation and statistical data processing performed by data obtained, so that the data which consist of desired information can be processed according to the needs.

\section{RESULTS AND DISCUSSIONS}

From the data obtained is found that the ratio of the number of female who admitted at one of the Universities in North Sumatra was greater than the number of male. This clearly shows that the paradigm that had claimed more men who had received education has turned out to be wrong. The statement above can be seen in Figure 2 below.
In terms of participation in education, female around the world are facing the same problem. Compared to the opposite sex, female's participation in formal education is much lower. In the countries where primary education is not compulsory, the number of female students generally only half or a third of the boys it was a study done at state universities in Kalimantan were carried out in 2005 (Amasari, 2005: 31). The study also refuted by the discovery of other facts that the GPA grade point average in graduate. For academic achievement seen from the GPA graduates can be seen in Figure 3 below.

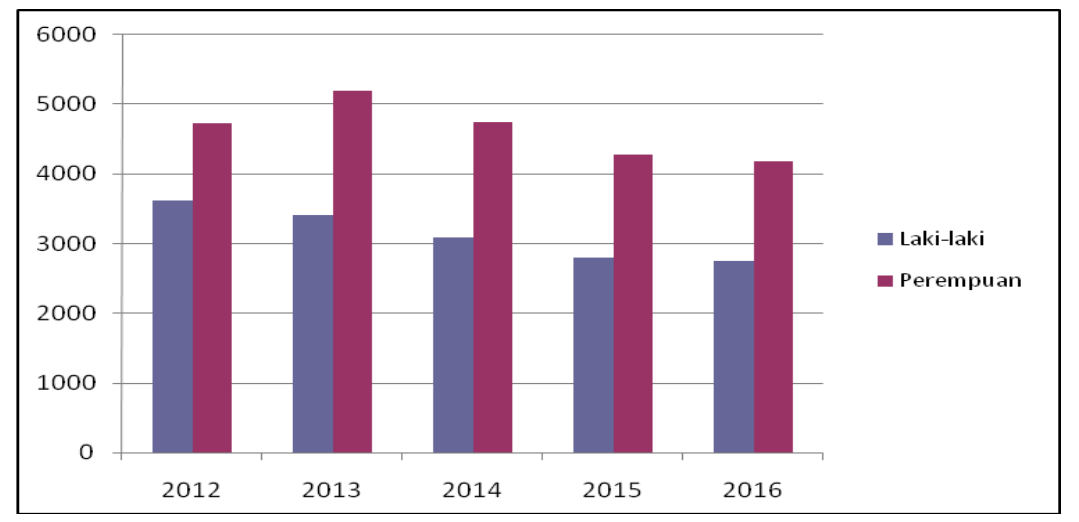

Figure 2. Comparison of Male and Female Admitted in State Universities

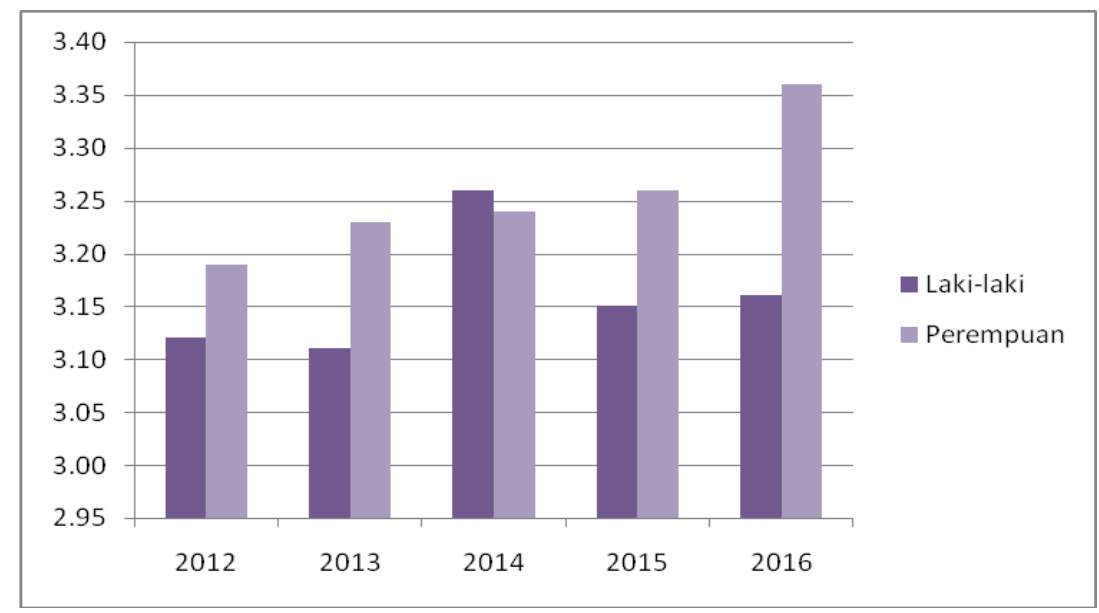

Figure 3. Comparison of the GPA by Gender

Through Figure 3 clearly seen that for only in 2014 the male gained better achievement than female in the average of graduate GPA, and the rest is achieved by female. Suryadi and Idris (2004) categorize the factors of gender gaps in education in four aspects, namely: 1) access is an opportunity or a chance in obtaining or using a particular resource, 2) Participation is the involvement or role 
of a person / group in an activity and or in decision making, 3) Control is the control or authority or power to make decisions, 4) the benefit is the usefulness of resources that can be enjoyed optimally (Suryadi, 2004).

\section{CONCLUSION}

The conclusion obtained through this research it is clear that the issue of gender on satt education is no longer an issue. It is evident from the number of female who admitted at State Universities and also seen also from the academic side. The academic side is the level of female graduate GPI grade point averagely higher than male seen from the data taken last 5 years.

\section{ACKNOWLEDGMENT}

This research was supported by University of Sumatera Utara. We thank our colleagues from Information System Center who provided insight and expertise that greatly assisted the research. All the faculty, staff members and lab technicians of Industrial Engineering Department, whose services turned my research a success. Dr. Himsar Ambarita, my mentor, whose reminders and constant motivation encouraged me to meet the deadlines.

My Wife, Kartika Widya Astuty and children, Omaar Al Faridzi Siregar and Alisha Rizki Siregar, family members and friends, without whom I was nothing; they not only assisted me financially but also extended their support morally and emotionally.

\section{REFERENCES}

Amasari (Member of PSG LAIN), Academic Research report Pendidikan Berujatuasan Gender,(Banjannasin: IAIN Antasari, 2005), hal. 31.

Azmi, Ilhaamie Abdul Ghani., Female career advancement in public service: a study in Indonesia, Procedia - Social and Behavioural Sciences 58 ( 2012 ) $298-306$.

Dogan, M. Kadir., The Causes Of Gender Inequality In College Education In Turkey, Procedia Social and Behavioral Sciences 15 (2011) 691-695.

Gapova, Elena., Gender equality vs. difference and what post-socialism can teach us, Female's Studies International Forum 59 (2016) 9-16.
García, Alfredo Martín, Gender history and the History of female in higher education: an educational innovation project, Procedia Social and Behavioral Sciences 161 ( 2014 ) $289-294$.

Grotti, Raffaele., Does gender equality increase economic inequality? Evidence from five countries., Research in Social Stratification and Mobility 45 (2016) 13-26.

Panitsidou, Eugenia A., Vocational education and training of unemployed female in Greece: An initial approach, Procedia - Social and Behavioral Sciences 69 ( 2012 ) 1729 - 1736.

Popa, Oana-Rica, Gender Discrimination and Education Practitioners. Reality, Perception, Possible Solutions, Procedia - Social and Behavioral Sciences 127 ( 2014 ) 459 - 463.

Salahodjaev, Raufhon, Intelligence and gender (in)equality: Empirical evidence from developing countries, Intelligence 52 (2015) 97-103.

Samarakoon, Shanika,. Does Education Empower Female? Evidence from Indonesia, World Development Vol. 66, pp. 428-442, 2015.

Shahtalebi, Somaye., Female's success factors from leadership in higher education, Procedia Social and Behavioral Sciences 15 (2011) 3644-3647.

Surjono, Gender Equality and Social Capital as Rural Development Indicators in Indonesia (Case: Malang Regency, Indonesia), Procedia - Social and Behavioral Sciences 211 ( 2015 ) $370-374$.

Suryadi, A, \& Idris, E.Kesetaraan Gender dalam Bidang Pendidikan (2004).

Youn, Jong-Tae., Female included engineering education in Korea, Procedia - Social and Behavioral Sciences 174 ( 2015 ) 1678 1683.

Yousefy, Alireza., Female, Employment and Higher education schoolings, Procedia Social and Behavioral Sciences 15 (2011) 3861-386 